\title{
CEASING COPYCAT BEHAVIOUR: DEVELOPING PRODUCT-DESIGN IDENTITY THROUGH INDUSTRY AND HANDCRAFT INTERACTION
}

\author{
ROMPENDO COM O COMPORTAMENTO DA CÓPIA: O \ \\ DESENVOLVIMENTO DA IDENTIDADE DE PRODUTOS POR \\ MEIO DA INTERAÇÃO ENTRE INDÚSTRIA E ARTESANATO
}

\section{Mariana Fonseca Braga}

ABSTRACT: The Brazilian industrial history and design education have not contributed to the construction of a design culture and to the preservation of cultural heritage, despite the richness and variety of its culture and renowned production of Brazilian designers. The urgency of transforming this scenario - characterized by a culture of copying - into innovative contexts has been reported in several publications. This study sheds light on the issue of copycat behaviour changes in Brazilian furniture industry through two practice-based cases analysis. These cases show the interaction between industry and craftwork towards design culture conception and cultural heritage preservation. Participant observation was the main method used to collect data in the first case (Pedra de Minas). The second case (Corn armchair) was based on a semi-structured interview addressed to the company's owner, as well as observation and analysis of archival sources such as brochures, materials used in exhibitions, and the company's website. Interdisciplinary literature review supported the understanding of the empirical cases and context regarding copycat behaviour. This research was focused on: drivers and barriers to integrating design innovation into small and medium-sized enterprises (SMEs); copycat behaviour (under-researched issue in the design field); product identity; industrial and handcraft systems and their relationship to design. The purposes of this paper are to contribute to the analysis of practice-based cases in an emerging economy, to inquiry relations between crafts, industry and design, proposing possibilities of bidirectional projects as potential sources to create value in companies and communities, to start understanding copycat behaviour related to product-design in the Brazilian furniture industry and its changes towards design innovation, to better understand the feasibility and importance of prototyping as well as their boundaries for design development in this context. The discussion and conclusion point out drivers and barriers found at the company's level and at the macro level, emphasizing the need to develop effective design policies and appropriate infrastructure in order to support design culture conception and cultural heritage preservation.

KEYWORDS: Copycat Behaviour; Design; Brazilian Furniture Industry; Crafts; SMEs.

RESUMO: A história do desenvolvimento industrial brasileiro e a educação em design não contribuíram para a construção de uma cultura de design e para a preservação da herança cultural, apesar da riqueza e variedade da cultura brasileira, e da reconhecida produção dos designers brasileiros. A urgência em transformar esse cenário caracterizado por uma cultura da cópia em direção a contextos inovadores tem sido relatada em diversas publicações. Este estudo visa contribuir para o entendimento da mudança do comportamento de cópia na indústria moveleira do Brasil partindo da análise de dois casos práticos. Os casos mostram a interação entre indústria e artesanato rumo à construção de uma cultura de design e à preservação do patrimônio cultural regional. O primeiro caso (Pedra de Minas) usa observação participante como principal método, o segundo (poltrona Corn) usa entrevista semiestruturada direcionada ao proprietário da empresa, observação e análise de materiais de divulgação e website da empresa. Revisão de literatura interdisciplinar foi utilizada para auxiliar o entendimento dos casos empíricos e dos contextos de cópia no qual estão imersos, abordaram-se os seguintes tópicos: desencadeadores e barreiras para a integração do design nas Pequenas e Médias Empresas (PME); o comportamento da cópia (tópico pouco conhecido na área de pesquisa em design); identidade do produto; sistemas de produção industrial e artesanal e suas relações com o design. Os objetivos deste artigo são: contribuir para a análise de casos práticos em uma economia emergente, investigar as relações entre

\section{How to cite this article:}

BRAGA, M. F. Ceasing copycat behaviour: developing product-design identity through industry and handcraft interaction. Gestão e Tecnologia de Projetos, São Carlos, v. 12, n. 2, p. 21-40. 2017. http://dx.doi.org/10.11606/gtp.v12i2.110536

Fonte de financiamento: This research is supported by the National Council for Scientific and Technological Development (Conselho Nacional de Desenvolvimento Científico e Tecnológico [CNPq]), Brazil.

Conflito de interesse: Declaram não haver Submetido em: 29/01/2016 Aceito em: 22/06/2017 
artesanato, indústria e design propondo possibilidades de projetos bidirecionais como potencial fonte de criação de valor na empresa e comunidade locais, começar a compreender o comportamento de cópia relacionado ao design de produto na indústria de móveis brasileira assim como sua mudança rumo a inovação orientada pelo design, entender melhor a importância da viabilidade para a manufatura e da prototipagem assim como suas fronteiras neste contexto. A discussão e a conclusão apontam os impulsionadores e as barreiras encontradas nos níveis micro (da empresa) e macro (do ambiente externo), enfatizando a necessidade de desenvolver políticas de design efetivas e infraestrutura adequada para apoiar a construção de uma cultura de design e a preservação do patrimônio cultural.

PALAVRAS-CHAVE: Comportamento de Cópia; Design; Indústria Brasileira de Móveis; Artesanato; PME.

\section{INTRODUCTION}

This paper was motivated by several questions that have not been fully answered in Brazil. It was inspired by two empirical cases that show the interaction of industrial and handcraft processes as source of identity and value. Despite the economic growth, industrial and cultural potential, Brazilian companies have not demonstrated the capacity to consolidate a design culture as a source of competitive advantage or as a strategic resource in mature industries, such as the furniture one. Even design as a form-giving ${ }^{1}$ process has faced obstacles related to the lack of structure (ROSA et al., 2007).

The five main goals of this study are:

1) To contribute to the analysis of empirical design cases in emerging economies. $^{2}$ The lack of practice-based cases in the design field is acknowledged and design has been considered a trial and error practice based on experimentation (BROWN, 2009) that does not assure, by itself, product success in the market, even though the field of exploration has broadened. ${ }^{3}$

2) To inquiry the interaction among handcraft, industry and design, exploring possibilities of bidirectional projects strategies that have already emerged in the Brazilian practice. It is not the intention to discuss preferences or aesthetics outputs but to provide strategies to work on product identity connected to local resources (people, their cultural heritage techniques and skills, and available materials in the territory) suggesting potential sources to create local value in a context in which enterprises have faced difficulties in doing so.

3) To start understanding the copycat behaviour in the Brazilian furniture industry and its possible reasons.

\footnotetext{
This is the second step in the Design Ladder tool developed by the Danish Design Centre (2001). The Design Ladder proposes four levels of design integration in the firm that are categorized from step 1 (non-design) to step 4 (design as strategy).

Developing x Emerging Brazil is included in two major group definitions: developing country or economy and emerging market. "The term developing used to denote low- and middle-income countries does not imply that all economies in the group are experiencing similar levels of development or that other economies have reached a preferred or final stage of development” (WORLD BANK, 2015). Emerging market, country or economy have been related to countries which have reached a rapid economic growth and integration into world markets (OECD, 2009) but these countries are still considered very risky for several reasons (EMERGING MARKETS, 2003) including inequality (OECD, 2011). We note that the terms are also used overlapped (see INTERNATIONAL MONETARY FUND, 2008, 2012). The emerging countries (markets or economies) are developing ones (e. g. Brazil and China are considered upper-middle income economies). It is possible to identify different groups of emerging economies depending on the source, aim of information or analysed subject (e. g. MORGAN STANLEY INVESTMENT FUNDS, 2015; TSOUNTA, 2014).

Product-service systems, strategic design, service design, design for policies, and social innovation are examples of fields that have widened the design perspective beyond the product-design issues or design as an outcome bounded by the material culture aspects. In this sense, design becomes an instrument of change, not just proposing solutions to problems but envisioning new opportunities, considering people's behaviour, quality of life and the need for change in diverse dimensions (economic, political, social, cultural, environmental).
} 
4) To provide insights about the change of direction from the copycat behaviour to a design culture supported by the empirical case, which shows how a small enterprise settled in a furniture cluster (characterized by this copycat culture) has started developing its design, linking its manufacture to the local handcraft system, while creating an armchair together with the local community. This case aims at clarifying the change in copycat culture towards a design culture.

5) To understand the importance of implementation and feasibility as well as the boundaries to introduce new projects into manufacture. The Pedra de Minas case inquiries this issue.

\section{METHODOLOGY}

This research approach is inductive, qualitative and exploratory. Two empirical cases were analysed. They demonstrate that cooperation between different stakeholders in local productive systems can be a source of product identity in a copy culture context. The Pedra de Minas case explores the idea of productive systems integration through design, waste from soapstone crafts was used as a source of regional identity. In addition, the Corn armchair case shows the enterprise's attitude towards design despite its unfavourable surrounding context.

Considering design as a phenomenon that is still not fully grasped within companies (D’IPPOLITO, 2014; TRUEMAN; JOBBER, 1998; WALSH, 1996), case study was the research strategy adopted. According to Yin (1994), this strategy is recommended when we study a contemporary phenomenon in a real context where the boundaries between context and phenomenon are not clearly defined.

Stake (2000) characterizes the case as a complex entity and a bounded system composed of diverse dimensions (e. g. cultural, psychological, physiological, economic). The criterion to select the cases considers Stake's observation (2000, p. 446): "Potential for learning is a different and sometimes superior criterion to representativeness".

These cases were built using multiple-method approach. The Pedra de Minas case was based on participant observation during the Industrial Design graduation project of this paper's author. The main methods used in the Corn armchair case were observation, semi-structured interview addressed to the owner of the company, informal conversations with the entrepreneur and archival sources (projects, exhibitions memories, company's brochures and website).

Literature review was used to support the analysis of these cases, based on topics that emerged from their practices and contexts and were not grasped just through the empirical evidence found. Hence, it was identified the need to introduce the Brazilian context through diverse sources that have described and explained the Brazilian conditions related to design (BORGES, 2011; ECONOMIC COMMISSION FOR LATIN AMERICA AND THE CARIBBEAN, 2015; MORAES, 2006; MORAES JUNIOR, 2002; ORGANISATION FOR ECONOMIC CO-OPERATION AND DEVELOPMENT, 2013; ORGANISATION FOR ECONOMIC CO-OPERATION AND DEVELOPMENT, 2014; ROSA et al., 2007). Furthermore, the literature review was interdisciplinary considering the under-researched copycat behaviour issue in the design field. The themes approached are: drivers and barriers to integrating design into micro, small and medium-sized enterprises (MSMEs) at the organizational level; copycat behaviour; product identity and features of industrial and craftwork processes. The third part describes empirical cases based on the interaction between handcraft and industry as source of product-identity. Afterwards, discussion and conclusion shed light on the paper's goals, and limitations and future research were pointed out. 


\section{Brazilian Context}

After a ten-year economic growth, Brazil has been experiencing an economic slowdown since 2010. Productivity growth in Brazil is associated with low value added sectors such as agriculture and mining, whereas manufacturing and services correspond to $20 \%$ of the Brazilian productivity growth, concentrating over $80 \%$ of value added and employment (ORGANISATION FOR ECONOMIC CO-OPERATION AND DEVELOPMENT, 2013). The potential of manufacturing and services to contribute to the productivity growth is underexplored despite the value added and employment rates related to these sectors.

The furniture industry is among the most important manufacturing businesses in Brazil, not only because of the importance of its production value but also for its potential to generate jobs (BRASIL, 2015). Minas Gerais is the third state in number of companies and the fourth in number of employees in Brazil, presenting 3.093 companies and 34.104 employees in 2015 (BRADESCO, 2017). The opportunity to innovate through design is identified in the furniture industry, which is not technology-intensive (GALINARI; TEIXEIRA JUNIOR; MORGADO, 2013; GEMSER; LEENDERS, 2001).

Although Brazilian culture can be considered rich and authentic, with a variety of craftwork, the reproduction of the same designs manufactured by many producers instead of developing a new product design is usual in Brazil. This context leads to cost-oriented markets. This means that products generally compete on price, and cost reduction is the main strategy applied to changes in goods. Hence, the copycat behaviour opposed to a design culture nurture is found. One of the results is the drop in the products quality and the dependence on specific retail customers. Moreover, even negative features are copied, such as ergonomic problems that are not recognized by manufacturers. Enterprises become vulnerable to retail's requirements instead of focusing on users and innovation.

Moraes (2006) identifies a European influence through the rationalfunctionalist thinking from Bauhaus and Ulm in the Brazilian Design education. The difficulty in finding its self-identity throughout the integration of cultural icons into the national design is also unleashed by the late and forced industrialization introduced in the 1960s during the dictatorship when multinational enterprises, mainly from United States, Europe and Japan, arrived in Brazil (MORAES JUNIOR, 2002). This process is known as modern colonialism and impacted the Brazilian society, culture and habits. The lack of evolution from this context leads the Brazilian design to an inferiority feeling (MORAES JUNIOR, 2002).

Borges (2011) points out the rupture of Brazil with its cultural roots. She explores the relationship between design and handcraft in Brazil as a means to recover missed roots and provide product identity related to the local culture and craftsmen, highlighting the importance of Lina Bo Bardi for Brazilian craftwork preservation and acknowledgement. In this context, design has a role in reinterpreting the cultural heritage skills and techniques supporting the development of products that fits the current users' needs and trends.

The Brazilian industry has historically devoted more to the domestic market than to exports (BRADESCO, 2017; GALINARI; TEIXEIRA JUNIOR; MORGADO, 2013; MORAES JUNIOR, 2002; ORGANISATION FOR ECONOMIC CO-OPERATION AND DEVELOPMENT, 2014). Despite some designers have demonstrated capacity to convey the Brazilian culture through meaningful design (MORAES, 2006), the Brazilian furniture industry is considered low technology based presenting structural problems that affect design and trade development. Most companies focus efforts on technological improvements to enhance their industrial park and manufacturing 
processes, and the development of product-design strategy is a low priority (ROSA et al., 2007, p. 97). The Brazilian Development Bank (Banco Nacional de Desenvolvimento Econômico e Social - BNDES) sectorial report (ROSA et al., 2007) identifies design as a key factor for competition and recognizes design problems in the furniture industry. The Brazilian furniture business is not design-oriented and competition is based on prices in low value added markets (GALINARI; TEIXEIRA JUNIOR; MORGADO, 2013). Most furniture firms are SMEs (Small and Medium-sized Enterprises) in Brazil (GALINARI; TEIXEIRA JUNIOR; MORGADO, 2013; ROSA et al., 2007).

\section{Drivers and barriers to introducing design innovation into SMEs}

the introduction of design culture within companies normally meets many obstacles - primarily the established culture and the natural resistance to change of organizations in which design culture seems to fight a daily war by being indissolubly bound to innovation

(DESERTI; RIZZO, 2014, p. 36).

Design has been considered a strategic resource for companies (BORJA DE MOZOTA, 2006; BRUCE; BESSANT, 2002; DELL'ERA; VERGANTI, 2007), and providing people what they want as well as value 'on time' and 'on budget' are guidelines to increasing the chances of designing well (BESSANT, 2002). Design has been related to the companies' benefits and considered a way to achieve innovation in organizations (BROWN, 2009; DESIGN COUNCIL, 2007; GEMSER; LEENDERS; 2001; MAEDA, 2015). Diverse models have been developed to categorize design evolution within enterprises such as the Design Management Staircase model (KOOTSTRA, 2009) and the Design Ladder (DANISH DESIGN CENTRE, 2001). However, what leads the company to change from non-design towards a design-oriented approach is still under-researched (few studies focus on this, e.g. DOHERTY et al., 2014). Furthermore, some companies are born design-oriented, which can be one of the reasons for this.

The four powers of design found in small and medium European design-oriented firms are defined by Borja de Mozota (2006) as: design as differentiator (as source of competitive advantage); design as integrator (as a resource that enhances new product development and favours modular and platform architecture of product lines); design as transformer (as a resource that creates new business activities and develops the company's ability to cope with change); and design as good business (as a resource that increases financial and economic values, and as a resource for society through inclusive and sustainable design). This model explores the role of design in different firm's levels and activities.

Companies exploit the use of design according to their vision of how design affects the enterprise and other stakeholders. Borja de Mozota (2006) defines design visions as design as styling, design as process and design as strategy. The firm's design vision matched with its management vision leads to the design management idea adopted by the enterprise. Different visions define different perspectives for creating value by design in each area of the enterprise and outside the company (other stakeholders).

Drivers and barriers to integrating design into SMEs at the organizational level (see table 1) have been investigated in the following fields: organizational culture and design, design management, product innovation, and design and innovation policies. In the case of small businesses, design strategy lies mainly on the experience and skills of the owner who tends to be in charge of management and strategies (BRUCE; COOPER; VAZQUEZ, 1999, p. 300). 
Table 1: Drivers and barriers to integrating design into SMEs at the organizational level

\begin{tabular}{c|ll|}
\hline \multicolumn{1}{|c|}{ Drivers } & \multicolumn{1}{c|}{ Barriers } \\
\hline \multirow{2}{*}{ Structure } & \multicolumn{1}{c}{ Scarce bureaucracy (MINTZBERG, 1992; SIVADES; } & Limited resources (ACKLIN, 2013; LARSEN; LEWIS, 2007) \\
& DWYER, 2000 apud MASSA; TESTA, 2008) & Limited in-house capabilities for conducting innovation \\
Great operational expertise (DAHL; MOREAU, 2002 & processes (ACKLIN, 2013; BRUCE; COOPER; VAZQUEZ, \\
apud MASSA; TESTA, 2008) & 1999; FILSON; LEWIS, 2000; HAUSMAN, 2005 apud \\
& MASSA; TESTA, 2008) \\
Flexible organizational structures (faster response & Underdeveloped education and training (LARSEN; LEWIS, \\
to changes) (CAWOOD, 1997; MINTZBERG, 1992) & 2007; ROMANO, 1990 apud MASSA; TESTA) \\
& Lack of management skills (ALTENBURG; MEYER-STAMER, \\
& 1999; LARSEN; LEWIS, 2007) \\
& Lack of manufacturing skills (LARSEN; LEWIS, 2007)
\end{tabular}

Culture Customer/users oriented (LARSEN; LEWIS, 2007; MASSA; TESTA, 2008)

Use design support to address immediate needs during a crisis (CAWOOD, 1997)

Motivating environment/external motivation (POIRIER; SCHWARTZ; EDDY; BERMAN; CHACOUR; WYNNE; CAVANAUGH; MARTIN; Cost-driven approach (MILLWARD; LEWIS, 2005) BYRNE; SANBERG, 2017; STERNBERG, 2006, 2012) Commitment of senior management (CAWOOD, 1997; SCHNEIDER; GIBET; COLOMB; ORAZEM; LOESCH; KASPARYAN; SALMINEN, 2015) Multi-disciplinary people are close to each other (POIRIER et al., 2017)

Collaboration among individuals from different backgrounds (POIRIER et al., 2017; LARSEN; LEWIS, 2007)

Great ability to use external networks (NOOTEBOOM, 1994; ROTHWELL; DODGSON, 1994 apud MASSA, TESTA, 2008)

Great ability to create alliances (VAN DIJK et al., 1997 apud MASSA; TESTA, 2008)

Face-to-face communication (MINTZBERG, 1992)

Lack of top management support (CAWOOD, 1997; FILSON; LEWIS, 2000; LARSEN; LEWIS, 2007; SCHNEIDER et al., 2015)

Lack of long-term strategic vision (CAWOOD, 1997; FILSON; LEWIS, 2000)

Too many pressures on business (COX, 2005; FILSON; LEWIS, 2000; LARSEN; LEWIS, 2007)

Weak external contacts (SRINIVASAN et al., 2002 apud MASSA; TESTA, 2008)

Influence of a dominant owner/manager (BRUCE et al., 1999; MILLWARD; LEWIS, 2005)

Lack of trust to build up partnerships (LARSEN; LEWIS, 2007) Clannish structures (SIVADES; DWYER, 2000 apud MASSA; TESTA, 2008)

ProductClear product development/design strategy (FILSON; LEWIS, 2000)

design Competitors and suppliers updated knowledge (LARSEN; LEWIS, 2007)

International market-focused orientation with

process effective internal and external communication (LARSEN; LEWIS, 2007)

Plan and resource market launch using stage gates process (LARSEN; LEWIS, 2007)

Early superior/differentiated product definition (LARSEN; LEWIS, 2007)

No clear new product development/design strategy (FILSON; LEWIS, 2000)

Lack of competitors and suppliers' knowledge (LARSEN; LEWIS, 2007)

Domestic market orientation (LARSEN; LEWIS, 2007)

Lack of market launch plan and resource with stage gates (LARSEN; LEWIS, 2007)

Lack of early superior/differentiated product definition (LARSEN; LEWIS, 2007)

Lack of customers/users' orientation (LARSEN; LEWIS, 2007)

\section{Source: Research data}

The lack of reported practice and literature that refer to design in the Brazilian (and emerging economies) enterprises is recognized despite the welldeveloped theory about design for the market (MARGOLIN; MARGOLIN, 2002).

Globalization has contributed to empowering emerging economies for global competition and collaboration (FRIEDMAN, 2005). On the other hand, design culture relies on "the necessity of rooting design deeply within the 
enterprise, which takes both a long time and the ability to adapt it to the specificity of the situation" (DESERTI; RIZZO, 2014, p. 56). The need to take in the local context qualities, in other words, to understand the territory and the way in which products are conceived and manufactured to grasp the relationships created involving production and consumption of products is emphasized by Krucken (2009, p. 17).

Design has its foundations mainly in Europe and the USA where approaches have been developed and used ranging from the process to the strategic level. Although design is considered a universal phenomenon, ${ }^{4}$ there are meaningful differences in the conditions for design development at the company level as well as at the macro level (education, policies and economy) in Latin America compared to the USA and Europe. These differences are related to the historical background, technological approach and development, macroeconomic policy, social inequality, lack of education and skills, and so on (ALTENBURG; MEYER-STAMER, 1999; ECONOMIC COMMISSION FOR LATIN AMERICA AND THE CARIBBEAN, 2015; ORGANISATION FOR ECONOMIC CO-OPERATION AND DEVELOPMENT, 2014). Enterprises in Latin America are born for diverse reasons too, especially SMEs (ALTENBURG; MEYER-STAMER, 1999).

The process of design at work in the company is not "an easy journey"; there are procedural difficulties and there is no guarantee of success (BESSANT, 2000). Design contributes to building the enterprise's vision and allows people to visualize it (ZURLO, 1999, p. 35). The contribution of design to organizations can range from product engineering aspects to strategic importance, shaping the company's vision.

\section{WHY ARE SOME ENTERPRISES IMITATING (OTHERS)?}

“when imitation is easy, markets don’t work well” TEECE, 1986, p. 285

Competition amongst firms is first focused on designs which are quite different from each other, and when a dominant design emerges it shifts to price (TEECE, 1986, p. 288). Despite the responsibility of the innovator for fundamental breakthroughs and design, when imitation is easy, imitators compete and can profit from others' innovations (TEECE, 1986, p. 288).

Literature on imitation, copy and plagiarism is scarce (SATOMURA; WEDEL; PIETERS, 2014). The followers' behaviour has been studied in fields such as marketing, economics, business, management, law, sociology and psychology. There is a lack of literature in the product-design field related to the copycat behaviour in companies. This issue leads to asking why enterprises are copying design products from other companies despite the design advantages reported in the last decades (e.g. DANISH DESIGN CENTRE, 2003; DESIGN COUNCIL, 2007, 2015; GEMSER; LEENDERS, 2001; RAE, 2013; 2014; ROY; RIEDEL, 1997). In order to contribute to this discussion, diverse perspectives ranging from the social and psychological (LITTLE et al., 2011; VAN HOREN; PIETERS, 2013; YANG et al., 2014) to the marketing, business (TEECE, 1986), design management (BORJA DE MOZOTA, 2006; DELL'ERA; VERGANTI, 2007; DESERTI; RIZZO, 2014; GEMSER; LEENDERS, 2001; HESKETT, 2009; ROY; RIEDEL, 1997) were considered in this paper. In addition, Altenburg and Meyer-Stamer (1999) contextualized the differences in the copy culture in Latin America. This behaviour cannot be grasped by looking at only one dimension or field.

The idea of copycat behaviour is linked to social learning that is first related to the non-humans behaviour. When a "model" female chooses a "target" male from two males being observed by other females, the latter are more likely to prefer the target male chosen by the model after watching the "model" female's decision (LITTLE et al., 2011). This behaviour has

Bonsiepe claims that design should be considered a universal phenomenon (Groll, 2015). 
also been observed in humans in a more complex manner in which social learning is a mechanism to spread preferences for certain traits, but human beings "preferentially copy the choices of individuals with high status or better access to critical information" (LITTLE et al., 2011, p. 373).

Although copying is negatively evaluated by people (VAN HOREN; PIETERS, 2012; YANG et al., 2013), even by children from different cultures (YANG et al., 2013), it is noticed that the consumer evaluation of copycats' brands depends on circumstances. People dislike copycat brands when uncertainty about the products' quality is low (they recognize the wellknown brands and others available) but this preference changes when uncertainty is high (they do not know the available brands) despite the recognition of imitation (VAN HOREN; PIETERS, 2013). Moreover, different kinds of imitation are identified and have been differently evaluated by consumers (VAN HOREN; PIETERS, 2013).

Despite the recognized importance of design for enterprises (BORJA DE MOZOTA, 2006; BRUCE; BESSANT, 2002; DANISH DESIGN CENTRE, 2003; DELL'ERA; VERGANTI, 2007; DESIGN COUNCIL, 2007; GEMSER; LEENDERS, 2001; TEECE, 1986) and even though investment in design expertise is considered low risk (BESSANT, 2002), the presence of a copy culture can be considered a way to reduce risks and investments, especially in SMEs where the company's foundation is a consequence of the unemployment condition as in the case of Latin America (ALTEMBURG; MEYER-STAMER, 1999). In this context, the owner of the company is worried about survival, fears unemployment and does not think as an entrepreneur. The need for immediate results to survive, and the lack of management skills to lead business, drive the company to the copycat behaviour (ALTEMBURG; MEYER-STAMEER, 1999).

When the enterprise is immersed in a copycat culture or imitation it is possible to imagine the hypothesis that the company will decrease efforts in product development, focusing on designs that have achieved success in the market, but this hypothesis has not been confirmed (DELL'ERA; VERGANTI, 2007; GEMSER; LEENDERS, 2001; ROY; RIEDEL, 1997). Dell'Era and Verganti (2007) analyze 2.000 products launched by 210 Italian firms and conclude that imitators tend to present higher product variety while innovators limit new product languages in the market. The authors deduce that imitators "miss the capability to interpret the complex evolution of products signs and languages in the market” (DELL'ERA; VERGANTI, 2007, p. 597). The Danish Design Centre (2003), Gemser and Leenders (2001) and Roy and Riedel (1997) demonstrate that more innovative design strategy leads to better results (e.g. turnover growth and exports).

Rosa et al. (2007) notice that Brazilian enterprises in the furniture industry have not established a product-design strategy despite the importance of design for competitiveness in this industry that is not technology-intensive. Some reasons considered are related to structural problems. Italian enterprises are considered references for the Brazilian furniture design, and the ease of imitation avoids the competition with Italian companies (ROSA et al., 2007).

Heskett (2009, p. 75) points out that designs are widely imitated by competitors because some companies choose the "fast-followers" strategy, producing successful innovations at low cost. In this sense, design is considered something that can be easily acquired at no cost (HESKETT, 2009, p. 75). On the other hand, Dell'Era and Verganti (2007) evidence that imitators are not doing the "right" copies because they are not able to recognize the dominant design or language in advance.

The lack of skills identified in different contexts (ALTENBURG et al., 1999; DELL'ERA; VERGANTI, 2007) leads the copycat behaviour. Adopting a copycat behaviour seems easier than creating novelty or developing new ways of thinking (see also STERNBERG, 2006, 2012). This social learning process of copying is identified from an instinctual behaviour to a design management style when to do it "right", one follows a "model", avoiding 
the effort to interpret changes in people's behaviour and needs, to develop criteria, to create options and to take decisions towards new directions. It can also be related to the lack of vision to associate design with diverse company and stakeholders' benefits or to the mindset of people (POIRIER et al., 2017) in charge of a small company's top management. Design is not adopted as a strategic resource to create value in the Brazilian furniture industry as it has been noticed in practice and sectorial reports despite research (FUNDAÇÃO GETULIO VARGAS, 2015) suggested this intention based on the perspective of the companies' representatives on product-design. This approach is questionable considering the lack of design experience, awareness and understanding usually found in SMEs even in European contexts (e.g. ARQUILLA et al., 2015; BRUCE; COOPER; VAZQUEZ, 1999; COX, 2005; FILSON; LEWIS, 2000; MILLWARD; LEWIS, 2005; SCHNEIDER et al., 2015), where design is considered a source of indigenous innovation. Moreover, design at the strategic level surpasses product-design issues. Another way to better visualize the design landscape in this industry could be looking at design leadership, design investment and design intensity (ROPER et al., 2009), which points out the level of importance of design within the company.

\section{Design and product identity}

Design is a way to convey persuasive ideas, attitudes, values and meanings to the users (BRUCE; BESSANT, 2002; DELL'ERA; VERGANTI, 2007).

Everybody has a self-image based on personal and social belonged values (BAXTER, 1998). According to Baxter (1998), it is part of the human nature to surround ourselves with goods which represent our self-image. The identity of products is built in the imaginary or reflexive level of people. It demonstrates how these people would like to be perceived by others through goods that belong to them which expresses their self-image and identity (NORMAN, 2008).

The contemporary individual seeks his identity and roots in a dynamic or "liquid" world in continuous change. Hence, desiring their own defined identity, which expresses their authenticity in the world, makes this individual feel that they belong to (or is identified with) a territory or a lived history (BAUMAN, 2001).

The 'celebration nation' trend suggested that natural and cultural heritage (the original symbols, lifestyles and traditions that were previously denied) in emerging markets such as Brazil, Russia, India and China (BRIC group) have been updated to become a source of pride for national consumers and to interested global ones (TRENDWATCHING, 2011).

Crafts are considered a source of design identity along with shapes, colour combinations, style, materials and their preparation, and when the object has identity it is unmistakable (BONSIEPE, 2011). Local products are cultural expressions related to the territory and its community, representing symbolic and cultural values that are an outcome of relationships built throughout time involving biodiversity, traditional production and habits (KRUCKEN, 2009).

\section{Design, industry, and crafts}

Scale manufacturing, characterized by labour division, plays a fundamental role in the birth of industrial design at the end of the XVII and in the beginning of the XVIII century. Social aspirations had to be transferred to a new production system defined by phases, specialized tasks and sectors in the factory, and product-design (or project) and manufacturing were separated (BÜRDEK, 2006; FORTY, 2007).

Two kinds of culture can be identified in the Design school. One is inclusive and considers the multiplicity of design regarding arts and craftwork interactions. The other is the polytechnic culture where design 
Figure 1: 'Industrianato' example: keychain made of soapstone

Source: Author's personal archive is a branch of architecture and interacts with engineering and is called industrial design (TROCCHIANESI; GUGLIELMETTI, 2012, p. 39).

The design culture is regarded as a mediator between producers and users (DESERTI; RIZZO, 2014). How to connect these worlds in a successful manner is still uncertain. Design is also related to the way of achieving innovation through interdisciplinary teamwork on problem-solving approach such as design-thinking (BROWN, 2009).

Historically, Brazil broke up with its cultural roots during the transition towards industrial (or scale) production (BORGES, 2011). The process of changing from craftwork to industrial manufacturing was forced in the dictatorship period when the design main skills and decisions were kept in the mature economies meanwhile manufacturing and design adjustments were performed in Brazil (MORAES JUNIOR, 2002).

Brazilian crafts can be categorized into two general groups. One includes indigenous and traditional craftwork, and the other is "industrianato". The first group is characterized by lower production and better market value, and by being close to the popular art in terms of expression, whereas the second one presents higher production capacity, uses less sophisticated techniques and has lower market value (FREITAS, 2006). Figures 1 and 2 show examples of "industrianato".
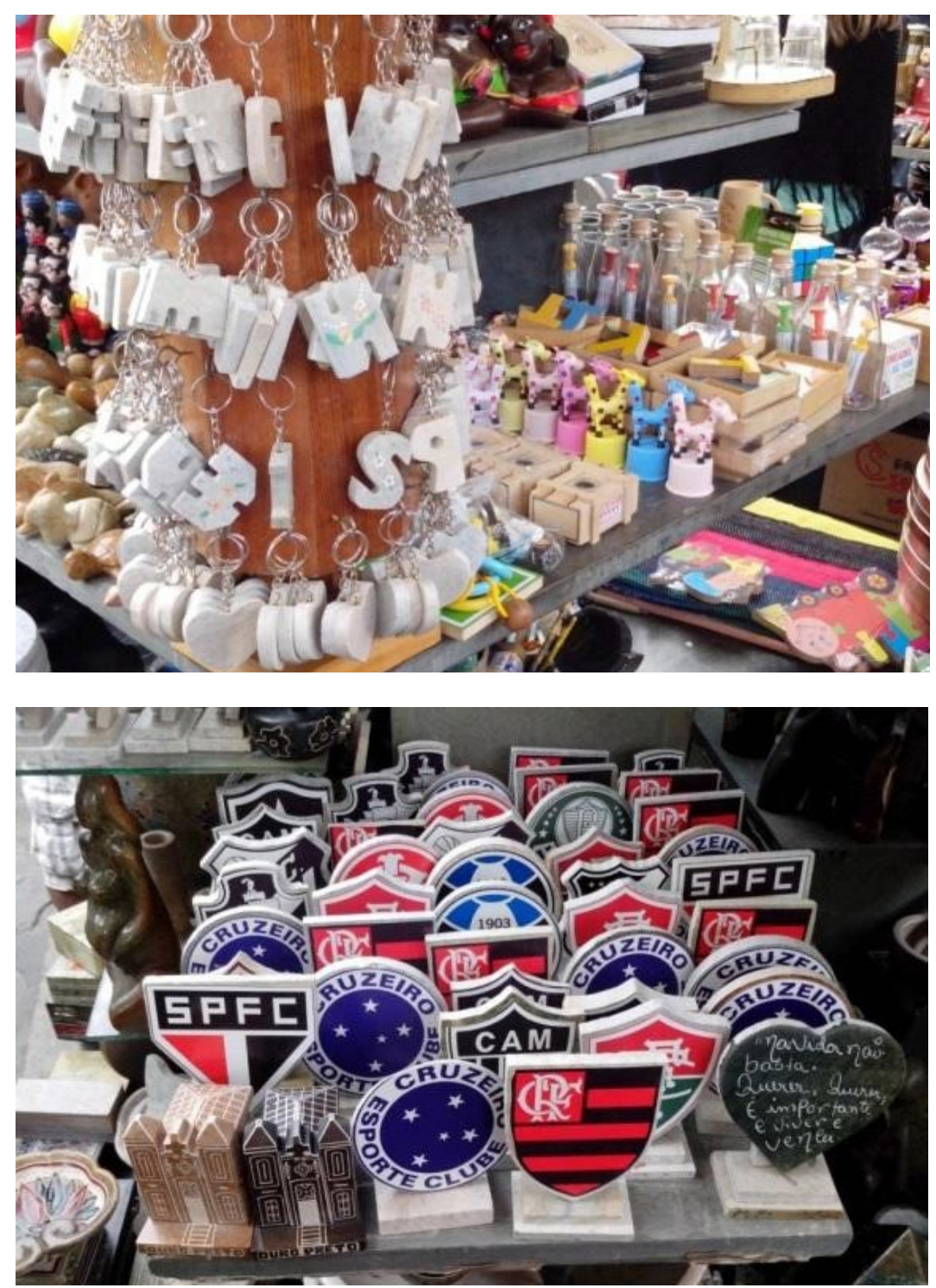

Figure 2: 'Industrianato' example: football teams' emblems inserted into pieces of soapstone

Source: Author's personal archive 
Technology advancements (e. g. rapid prototyping, Computer Numerical Control (CNC) technologies and so on) (VOLPATO et al., 2007) and the emergence of new forms of manufacturing (e. g. flexible manufacturing) bring different possibilities for products and production. Design tests can be performed faster in industry through prototypes that also communicate ideas and enable companies to get feedback from users, suppliers and interdisciplinary teams (CLARK; WHEELWRIGHT, 1993; BROWN, 2009).

Crafts are not just related to the handmade artefacts but to the opportunity to make complex-shape products that can be perceived as craftwork, and to produce personalized goods through rapid prototyping technologies where the distinction between project and manufacture becomes blurred.

Trocchianesi and Guglielmetti (2012) identify types of interaction between industry and crafts mediated by design. In this context, the role of design is also to provide new uses and signs for crafts, contributing to keep the cultural heritage alive. Bidirectional projects' approach is a way to develop product identity and customized products, considering also technological advancements. In this approach, design has an innovative role, interpreting crafts and transferring them into the entrepreneurial contexts, designing new contexts for use through the fusion of languages and techniques (TROCCHIANESI; GUGLIELMETTI, 2012).

Reaching novelty is related to the human being creativity deployment. Technologies can support scaling up a product production; however, they are not valuable per se - they become valuable depending on the way they are interpreted and used to create value to users in a defined context. The productivity concept lies on the demand issue. It is not enough to produce more if there are not people willing to buy the product (SLACK; BRANDONJONES; JOHNSTON, 2009). The ability to change direction or to identify what dimensions are worthy to be improved or to receive innovation is crucial in the design management field, otherwise "that effort will be wasted if the dimension you improve is not the one that matters most to the customer" (PILDITCH, 1990, p. 20, see also VERGANTI, 2016). Thus, identifying what can be worthy on the demand side is an overlapping matter that concerns design management, design leadership, marketing and production management.

\section{Pedra de Minas' furniture line: cultural heritage through craft's waste}

Pedra de Minas line was developed in 2005. It was the final project in the Industrial Design course at the University of the State of Minas Gerais (Universidade do Estado de Minas Gerais [UEMG]). The student who developed the design was a trainee at the furniture company that backed the prototype development.

This project emerged from the need to characterize inns in a historical touristic area, Estrada Real, which is part of Minas Gerais history and development. Regional productive systems, referred to carpentry factories and crafts, were considered. The region is a reference in local crafts.

The price had to be affordable for the local lodgings conditions and the furniture should convey regional cultural values. During fieldwork, in the artisans' communities, it was observed that the process of crafting soapstone generated small pieces of stones which could not be used to make objects. From this evidence, the use of waste from craftwork as source of local identity was considered throughout the project.

The users (tourists) ranged from adventurers and backpackers to elderlies. The habits of these travellers were studied and used as a source for the project inspiration-information and criteria for the selection of ideas.

The furniture had to be easy to manufacture and possible to be produced in the local SMEs. The main materials used by these firms were MDF (Medium Density Fiberboard) and wood. The selected material was MDF, once the use of 
Figure 3: Pedra de Minas Source: Author's personal archive wood was not a common feature among most producers, and that which can be made of MDF (as it was found in the supplier) can be made of wood, but the inverse is not possible according to the local productive practices at that time.

The technological requirements led to developing the furniture using productive processes that were available in the average furniture producer in that context. The DFMA (Design for Manufacture and Assembly) approach (BOOTHROYD; DEWHURST; KNIGHT, 2002) contributed to developing intuitive assembly-disassembly features favouring transport, package, maintenance and modularity to build different furniture pieces using the same design and product parts.

The issue that arose was how to incorporate the crafts' waste into the industrial MDF parts of the furniture. Among the solutions exploited, the selected one was to standardize soapstone residue which was inserted into the MDF parts that were torn up by a CNC.
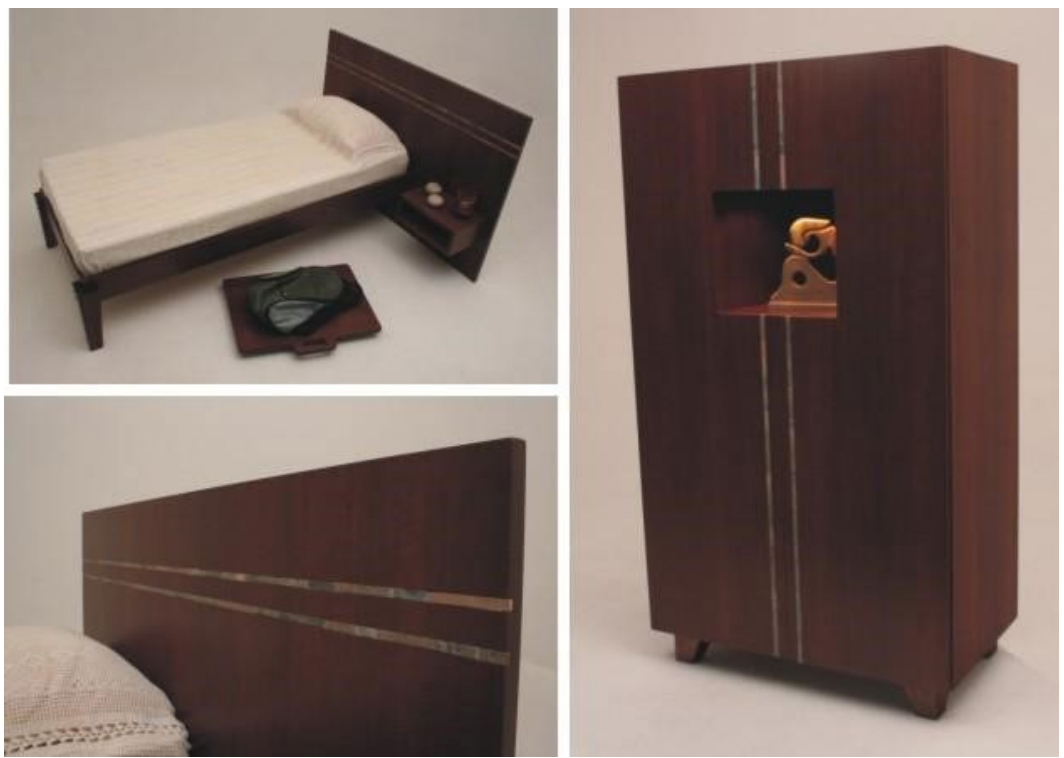

Soapstone presents different ranges of colour: from greys and pinks to greens. The effect of the soapstone's waste was the aesthetics' differentiator, enabling contrast, touch sensation and connection with the cultural heritage. Other features were defined based on users' needs such as a mobile support inspired by backpackers' behaviour and a small wardrobe considering elderly's habits when they travel. In addition, a niche for local crafts exhibition was included in the wardrobe in order to foster the trade of regional craftwork.

Pedra de Minas participated in the major Latin America furniture exhibition: Movelsul in 2006, in Bento Gonçalves (Rio Grande do Sul, Brazil). The furniture was exhibited in the Design Hall section.

\section{The Corn Armchair: Furniture Manufacturer and Artisans Community Joint Development}

Nova América was founded in 1994 in Ubá, Minas Gerais, Brazil, and is the company which produces the Corn armchair. Ubá represents one of the most important furniture clusters in Brazil.

The company sells its products in six states, from south-east to northeast, in Brazil. The Corn armchair is manufactured through traditional processes adopted by the couch industry in the furniture cluster, but its arms are made from corn straw which is woven by women artisans who 
live in the region what makes this armchair different compared to other similar furniture in the market.

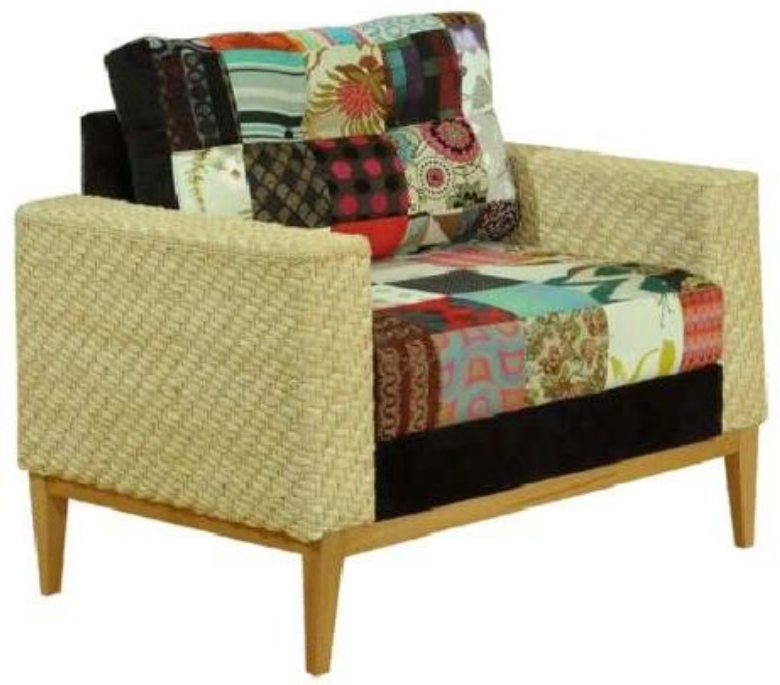

The first contact with the artisans' community happened on the occasion of a local event known as Potato Fair. The craftsmen community worked on dolls made from corn straw, however, the earnings resulting from the dolls were scarce. Besides corn straw, the dolls used a framework of wood, that came from the local furniture industry waste.

The entrepreneur envisioned an opportunity to develop some parts of the Corn armchair in collaboration with the artisans. He started delivering the wooden framework of the armchair when the truck went to deliver pieces of wood for the doll production, and the truck returned with the woven armchair arms. The access to the community was hard because the road was bad.

The artisans chose the kind of texture that would be created by weaving the corn straw. The Corn armchair development helped to increment the community income, it became a second option of earning money and also contributed to the maintenance of traditional skills and techniques of the community cultural heritage in corn straw, once the doll business was not going well. Professional designers did not take part in the design process, the project was developed by an employee with a background in couch manufacture.

According to the entrepreneur, the launch of Corn armchair attracted attention but was not financially successful in the beginning, because the cost was higher than other products. Another constraint reported was related to the commercialization, it was not addressed to the 'right' public that recognizes the value of handmade products. Although sales are not high compared to other products by the company, the perceived value and profit margin are higher than others, according to the owner.

"Nova América has as one of the principles to interact with several actors, among them craftsmen and small carpenters. We believe that we can provide them conditions to present their work, their skills and thereby improve their self-esteem, their working conditions and improve their income" ${ }^{\prime 5}$ (NOVA AMERICA ENTREPRENEUR, 2015).
Figure 4: The Corn armchair Source: Nova América website 


\section{DISCUSSION AND CONCLUSION}

The interaction between industrial and craft processes cannot be considered an issue of technological barriers. It can be considered, as design, an issue of vision. Local craftwork can be a source of local identity, as noticed by Trocchianesi and Guglielmetti (2012), Bonsiepe (2011), Borges (2011), and Krucken (2009), not just related to traditional crafts but connected to the local enterprises' design system.

If Brazil has broken up with its roots (BORGES, 2011; MORAES JUNIOR, 2002) and the copycat behaviour is common among the furniture industry firms, it is not only related to organizations' culture, but to a range of disadvantages, such as the lack of skills, quality of education and other reported conditions to move towards more innovative contexts (ALTENBURG; MEYER-STAMER, 1999; ECONOMIC COMMISSION FOR LATIN AMERICA AND THE CARIBBEAN, 2015; EUROPEAN COMISSION, 2015; GALINARI; TEIXEIRA JUNIOR; MORGADO, 2013; ORGANISATION FOR ECONOMIC CO-OPERATION AND DEVELOPMENT, 2013; ORGANISATION FOR ECONOMIC CO-OPERATION AND DEVELOPMENT, 2014; ROSA et al., 2007). The studied cases are examples of efforts to overcome these barriers and to build product-design identity.

Pedra de Minas case shows that it is possible to appropriate local values considering regional networks including local enterprises, craftsmen, lodgings, and tourists (users) requirements during the design process. The design feasibility was crucial in practice in order to prototype the furniture. However, the lack of experience in introducing new ideas into production reduces the ability of company's members to analyse and envision ways of making a prototype in diverse stages of the prototyping process. They tend to use methods, processes and materials that they are used to. This barrier contributes to the difficulty in achieving unique feasibility solutions to a new product-design in an interdisciplinary way, fully appreciating the diverse company's member skills and fostering the development of new ones.

The distrust among local stakeholders is a recognized constraint in Latin America (ALTENBURG; MEYER-STAMER, 1999). The Corn armchair case is an example that this boundary can be overcome through the development of partnership and the ability to use external networks towards a shared goal. The use of local productive techniques and materials along with the increment of the artisans' income contribute to the cultural heritage preservation. On the other hand, the enterprise has the opportunity to develop the product identity in a unique manner.

The Corn armchair case demonstrates the capacity of generating new visions connected to local communities' potentialities. In this case, the local social event (Potatoes Fair) and the entrepreneur mindset were fundamental to make the joint action a reality and to introduce a new practice in the company culture. As stated by Bruce, Cooper and Vazquez (1999), SMEs are managed in a personalized way, where the experiences and skills of the individual (generally the owner) become crucial. Despite an unfavourable environment to develop and implement new ideas, the entrepreneur's intrinsic motivation and mindset (see POIRIER et al., 2017; STERNBERG, 2006; 2012) were drivers to surpass the constraints, envisioning and deploying new opportunities.

The difficulty of commercialization can be considered a barrier, regarding the lack of a structured and diffused design knowledge throughout the firm's members and processes from ideas to market implementation with the participation of diverse stakeholders. Other constraints are related to the external environment such as the costoriented market that is historically focused on domestic market, and the lack of design awareness and knowledge diffusion among stakeholders (e.g. users, suppliers, distributors, salesmen). 
The introduction of a design culture requires long run strategies and experience in design, and the lack of an appropriate environment puts at risk the development, continuity or evolvement of this approach towards design innovation. Hence, the need for appropriate infrastructure and effective design policies that support design education and diffusion at diverse levels (from micro to macro) is pointed out.

The two cases analysed in this paper are sources of possible ideas to create value by design considering the local identity, and to engage with diverse stakeholders that play a fundamental role in the local cultural heritage maintenance. The creation of value by design is not just related to economic assets but to the company learning in the process of implementing changes (see for instance BORJA DE MOZOTA, 2006) as well as to social benefits.

\section{LIMITATIONS AND FUTURE RESEARCH}

The cases analysed highlight the local potential for product design and identity. However, they demonstrate empirical evidence from specific contexts and time. Pedra de Minas case was experimental and the products were not introduced into the market. The issue of scaling up this furniture should be studied in-depth to better understand the sustainability for crafts cultural heritage because of the soapstone waste use. The furniture production has a different scale and time.

This paper is focused on product-design aspects related to the use of local resources or potentialities. The potential of the territory and its cultural heritage can be valuable sources of languages and identities for companies ranging from product-design to strategic design. The strategic level was not fully explored in this study.

Moreover, the Corn armchair case is closely related to the enterprises' owner vision, intrinsic motivation and action to develop the product together with the craftsmen community. The innovator behaviour that counteracts unfavourable environment to innovate was not inquired in-depth through a literature review which could contribute to discuss this feature thoroughly.

To grasp how a design culture can be introduced, creating value, ceasing copy culture cycle and enabling identity development, is still an issue to be investigated in-depth in a longitudinal study. For instance, some questions are: how can a design culture be built into a small company, breaking up with the established copycat behaviour and inspiring innovation? How can design policies be effective in these contexts?

\section{ACKNOWLEDGEMENTS}

I am thankful for the contribution and support of the companies that took part in this study. I am also grateful to CNPq, and to Politecnico di Milano.

\section{REFERENCES}

ACKLIN, C. Design Management Absorption Model: A Framework to Describe and Measure the Absorption Process of Design Knowledge by SMEs with Little or No Prior Design Experience. Creativity and Innovation Management, Medford, v. 22, n. 2. p. 147-160, 2013.

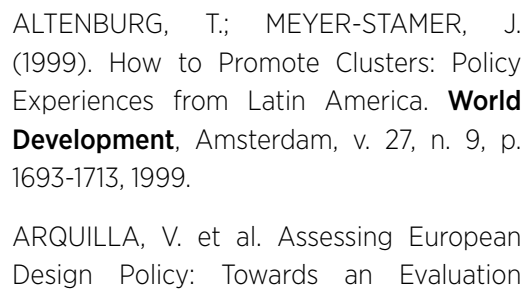

ALTENBURG, T.; MEYER-STAMER, J. (1999). How to Promote Clusters: Policy Experiences from Latin America. World Development, Amsterdam, v. 27, n. 9, p. 1693-1713, 1999

ARQUILLA, V. et al. Assessing European Design Policy: Towards an Evaluation 
Culture. In: MERONI, A.; COLLINA, L; GALLUZZO, L. (Eds.). Culumus Conference: The Virtuous Circle. Milan: McGraw-Hill Education, 2015. p. 915-926. Disponivel de: $<$ https://goo.gl/PL1mQQ>. Acesso em: 30 maio 2016

BAUMAN, Z. Modernidade líquida. Rio de Janeiro: Zahar, 2001.

BAXTER, M. Projeto de produto: guia prático para o design de novos produtos. São Paulo: Blucher, 1998.

BESSANT, J. Why design? In: BRUCE, M.; BESSANT, J. Design in business: strategic innovation through design. London: Financial Times Prentice Hall, 2002. p. 3-17.

BONSIEPE, G. Design, cultura e sociedade. São Paulo: Blucher, 2011.

BOOTHROYD, G.; DEWHURST, P.; KNIGHT, W. Product Design for Manufacture and Assembly. New York: Marcel Dekker, 2002.

BORGES, A. Design + artesanato: 0 caminho brasileiro. São Paulo: Terceiro Nome, 2011.

BORJA DE MOZOTA, B. (2006). The Four Powers of Design: A Value Model in Design Management. Design Management Review, Malden, v. 17, n. 2, p. 43-53, 2006.

BRADESCO. Departamento de Pesquisas e Estudos Econômicos. Indústria de Móveis. Economia em dia, Osasco, 2017. Disponível em: <https://goo.gl/pvm9Dr>. Acesso em: jun. 2017.

BRASIL. Ministério do Desenvolvimento, Indústria e Comércio Exterior. Cadeia Produtiva de Madeira e Móveis. Brasília, DF: MDIC, 2015. Disponivel em: <https://goo.gl/ QsREMr>. Acesso em: 11 set. 2015.

BROWN, T. Change by design: how design thinking transforms organizations and inspires innovation. New York: Harper Collins, 2009.

BRUCE, M.; BESSANT, J. Design definitions and management processes. In:

Design in business: strategic innovation through design. London: Financial Times Prentice Hall, 2002. p. 1-2.

BRUCE, M.; COOPER, R.; VAZQUEZ, D. Effective design management for small businesses. Design Studies, Amsterdam, v. 20, n. 3, p. 297-315, 1999.

BÜRDEK, B. E. História, teoria e prática do design de produtos. São Paulo: Blucher, 2006

CAWOOD, G. Design Innovation and Culture in SMEs. Design Management Review, Malden, v. 8, n. 4, p. 66-70, 1997.
CLARK, K. B.; WHEELWRIGHT, S. C. Managing New Product and Process Development: text and cases. New York: Free Press, 1993. 896p.

COX, G. Cox Review of Creativity in Business: building on the UK's strengths. 2005. Disponivel em: <https://goo.gl/ ysyo99>. Acesso em: 3 jun. 2016

DANISH DESIGN CENTRE. The Economic Effects of Design. Copenhagen: National Agency for Enterprise and Housing. 2003. Disponivel em: <https://goo.gl/hCJCQe>. Acesso em: 3 jun. 2016

DANISH DESIGN CENTRE. The Design Ladder: four steps of design use. Copenhagen: Danish Business Authority, 2001. Disponível em: <https://goo.gl/ zq8bcn>. Acesso em: 3 jun. 2016

DELL'ERA, C.; VERGANTI, R. Strategies of Innovation and Imitation of Product Languages. The Journal of Product Innovation Management, Medford, v. 24, n. 6, p. 580-599, 2007

DESERTI, A.; RIZZO, F. Design and the Cultures of Enterprises. Design Issues, Cambridge, MA, v. 30, n. 1, p. 36-56, 2014.

DESIGN COUNCIL. The Design Economy: The value of design to the UK economy. Executive summary. London, 2015. Disponivel em: <https://goo.gl/6HLsAV>. Acesso em: 3 jun. 2016

DESIGN COUNCIL. The Value of Design: Factfinder report. London, 2007. Disponível em: <https://goo.gl/bdiApB>. Acesso em: 23 abr. 2015.

D'IPPOLITO, B. The importance of design for firms' competitiveness: A review of the literature. Technovation, Amsterdam, v. 34, n. 11, p. 716-730, 2014.

DOHERTY, R. et al. Climbing the Design Ladder: Step by step. In: DMI: $19^{\text {th }}$ ACADEMIC DESIGN MANAGEMENT CONFERENCE. London: London College of Fashion, 2014. p. 2576-2597.

ECONOMIC COMMISSION FOR LATIN AMERICA AND THE CARIBBEAN. The European Union and Latin American and the Caribbean in the new economic and social context. Bonn: German Cooperation; Brussels: European Union, 2015. Disponível em: <https://goo.gl/VfKMua>. Acesso em: 16 jun. 2015

EMERGING MARKETS. In: Financial Dictionary. [S.I.]: The Free Dictionary, 2003. Disponível em: <https://goo.gl/ExnD9q>. Acesso em 24 jun. 2015 
EUROPEAN COMISSION. AL-INVEST 5.0: inclusive Growth for Social Cohesion in Latin America: guidelines for grant applicants. Brussels: European Comission, 2015. Disponível em: <https://goo.gl/XzHo6P>. Acesso em: 16 jun. 2015.

FILSON, A.; LEWIS, A. Barriers between Design and Business Strategy. Design Management Review, Malden, v. 11, n. 4, p. 48-52, 2000.

FORTY, A. Objeto de desejo: design e sociedade desde 1750. São Paulo: Cosac Naify, 2007.

FREITAS, A. L. C. Design e Artesanato: Uma experiência de inserção da metodologia de projeto de produto. 2006. Dissertação (Mestrado em Engenharia de Produção) Escola de Engenharia, Universidade Federal de Minas Gerais, Belo Horizonte, 2006.

FRIEDMAN, T. L. The world is flat: a brief History of the Globalized World in the Twenty-first Century. London: Penguin, 2005

FUNDAÇÃO GETÚLIO VARGAS. O Impacto do Design no Desempenho das Empresas pesquisa setorial. Porto Alegre: Pequenas Empresas e Grandes Negócios, 2015 Disponível em: <https://goo.gl/czhGaR>. Acesso em 10 abr. 2015.

GALINARI, R.; TEIXEIRA JUNIOR, J. R.; MORGADO, R. R. A competitividade da indústria de móveis do Brasil: situação atual e perspectivas. BNDES Setorial, Brasília, DF, n. 37, p. 227-272, 2013. Disponível em: <https://goo.gl/DRva34>. Acesso em: 4 ago. 2015.

GEMSER, G., LEENDERS, M. A. A. M. How integrating industrial design in the product development process: impacts on company performance. Journal of Product Innovation Management, Amsterdam, v. 18 n. 1, p. 28-38, 2001.

GROLL, S. Traces and Hopes of Design Research: An Interview with Gui Bonsiepe, Klaus Krippendorff, Siegfried Maser, and René Spitz. Design Issues, Cambridge, MA v. 31, n. 1, p. 18-31, 2015

HESKETT, J. Creating economic value by design. International Journal of Design, Taipei, v. 3, n. 1, p. 71-84, 2009.

INTERNATIONAL MONETARY FUND. Emerging and developing economies/ Countries. Washington, DC, Apr. 2008 Disponível em: <https://goo.gl/waC9eA>. Acesso em: 24 jun. 2015.

INTERNATIONAL MONETARY FUND. Emerging, Developing Economies Now More Resilient. Washington, DC, Sep. 2012.
Disponível em: <https://goo.gl/MRzTwg> Acesso em 24 jun. 2015.

KOOTSTRA, G. L. The incorporation of design management in today's business practices: an analysis of design management practices in Europe. Rotterdam: Centre for Brand, Reputation and Design Management, 2009. Disponível em: <https://goo.gl/XRh2Fd>. Acesso em 24 jun. 2015.

KRUCKEN, L. Design e território: valorização de identidades e produtos locais. Barueri: Studio Nobel, 2009.

LARSEN, P.; LEWIS, A. How Award-Winning SMEs Manage the Barriers to Innovation. Creativity and Innovation Management, Medford, v. 16, n. 2, p. 142-151, 2007.

LITTLE, A. C. et al. Social learning and human mate preferences: a potential mechanism for generating and maintaining between-population diversity in attraction. Philosophical Transactions of the Royal Society, London, v. 366, n. 1563, p. 366-375, 2011.

MAEDA, J. \#DesignIn Tech Report. KPCB, San Francisco, mar. 2015. Disponível em: <https:// goo.gl/PWf1Ar>. Acesso em 23 abr. 2015.

MARGOLIN, V:; MARGOLIN, S. A "Social Model" of Design: Issues of Practice and Research. Design Issues, Cambridge, MA, v. 18, n. 4, p. 24-30, 2002.

MASSA, S.; TESTA, S. Innovation and SMEs: Misaligned perspectives and goals among entrepreneurs, academics, and policy makers. Technovation, Amsterdam, v. 28, n. 7, p. 393-407, 2008

MILLWARD, H.; LEWIS, A. Barriers to successful new product development within small manufacturing companies. Journal of Small Business and Enterprise Development, Bingley, v. 12, n. 3, p. 379-394, 2005

MINTZBERG, $H$. Structure in fives designing effective organizations. New Jersey: Prentice Hall, 1992.

MORAES, D. Análise do design brasileiro: entre mimese e mestiçagem. São Paulo: Blucher, 2006

MORAES JUNIOR, D. II rapporto localeglobale: nuova sfida ed opportunità progettuale: il Brasile come caso locale. 2002. Tese (Doutorado em Design) Politecnico di Milano, Milão, 2002.

MORGAN STANLEY INVESTMENT FUNDS. Emerging Markets Equity Fund. Investment Management, New York, 31 jul. 2016. 
Disponível em: <https://goo.gl/GL5Dja>. Acesso em: 24 jun. 2015.

NORMAN, D. A. Design emocional: por que adoramos (ou detestamos) os objetos do dia-a-dia. Rio de Janeiro: Rocco, 2008.

ORGANISATION FOR ECONOMIC COOPERATION AND DEVELOPMENT. Globalisation and Emerging Economies. Paris: OECD, 2009. Disponível em: <https:// goo.gl/CrkxqK>. Acesso em: 24 jun. 2015

ORGANISATION FOR ECONOMIC COOPERATION AND DEVELOPMENT. Latin American Economic Outlook 2015: Education, Skills and Innovation for Development. Paris: OECD, 2014. Disponível em: <https://goo.gl/FNFGth>. Acesso em: 16 jun. 2015.

ORGANISATION FOR ECONOMIC COOPERATION AND DEVELOPMENT. OECD Economic Surveys: Brazil 2013. Paris: OECD, 2013. Disponivel em: <https://goo.gl/ iY4r5y> Acesso em: 16 jun. 2015.

ORGANISATION FOR ECONOMIC COOPERATION AND DEVELOPMENT. Special Focus: Inequality in Emerging Economies (EEs). Paris: OECD, 2011. Disponível em: <https://goo.gl/oaPXaQ>. Acesso em: 24 jun. 2015.

PILDITCH, J. Using design effectively. In: GORB, P. (Ed.). Design management: papers from the London Business School. London: Architecture Design and Technology Press, 1990. p. 13-23.

POIRIER, V. et al. Thoughts on improving innovation: what are the characteristics of innovation and how do we cultivate them? Technology and Innovation, Tampa, v. 18, n. 4, p. 319-330, 2017

RAE, J. What is the real value of design? Design Management Institute and Motiv Strategies, Boston, p. 1-9, 2014. Disponível em: <https://goo.gl/PxxGM5>. Acesso em: 11 fev. 2016

RAE, J. What is the real value of design? Design Management Review, Malden, v. 24, n. 4, p. 30-37, 2013. Disponível em: <https:// goo.gl/jSncvF>. Acesso em: 11 fev. 2016.

ROPER, S. et al. Measuring sectoral innovation capability in nine areas of the UK economy: report for NESTA innovation index project. London: NESTA, 2009. Disponível em: <https://goo.gl/2zNydy> Acesso em 17 abr. 2017.

ROSA, S. E. S. et al. O setor de móveis na atualidade: uma análise preliminar. BNDES Setorial, Brasília, DF, n. 25, p. 65-106, 2007. Disponível em: <https://goo.gl/ghG2P9>. Acesso em: 15 set. 2015
ROY, R.; RIEDEL, J. Design and innovation in successful product competition. Technovation, Amsterdam, v. 17, n. 10, p. 537-548, 1997.

SATOMURA, $T_{\text {.; }}$ WEDEL, $M_{\text {.; }}$ PIETERS, R. Copy Alert: A Method and Metric to Detect Visual Copycat Brands. Journal of Marketing Research, New Orleans, v. 51, n. 1, p. 1-13, 2014.

SCHNEIDER, J. et al. Supporting design driven innovation: a review of selected programmes. Paris: Agence por la Promotion de la Creátion Industrielle, 2015. Disponivel em: <https://goo.gl/rVCP8F>. Acesso em: 24 maio 2016.

SLACK, N.; BRANDON-JONES, A.; JOHNSTON, R. Administração da produção. 3. ed. São Paulo: Atlas, 2009.

STAKE, R. E. Case studies. In.: DENZIN, N. K.; LINCOLN, Y. S. (Eds.). 2000. Handbook of qualitative research. 2. ed. Thousand Oaks: Sage. p. 435-454.

STERNBERG, R. J. The Nature of Creativity. Creativity Research Journal, Abington, $v$. 18, n. 1, p. 87-98, 2006

STERNBERG, R. J. The Assessment of Creativity: An Investment-Based Approach. Creativity Research Journal, Abington, $v$. 24, n. 1, p. 3-12, 2012

TEECE, D. J. Profiting from technological innovation: implications for integration, licensing and public policy. Research Policy, Amsterdam, v. 15, n. 6, p. 285-305, 1986

TRENDWATCHING

Celebration Nation. London, [2011]. Disponível em: $\quad<$ http://trendwatching.com/ trends/10trends2013/?celebrationnation>. Acesso em 11 fev. 2014.

TRUEMAN, M.; JOBBER, D. Competing through Design. Long Range Planning, Amsterdam, v. 31, n. 4, p. 594-605, 1998.

TROCCHIANESI, R.; GUGLIELMETTI, I. Elementos de reconhecimento do design na multiplicidade e "multiversalidade" das diversas dinâmicas de relação com o artesanato. In: Jaña, A.; Abreu, I.; Albino, C. (Orgs.). Design, artesanato e indústria. Amieira: Greca Artes Gráficas, 2012. p. 30-39.

TSOUNTA, E. Slowdown in Emerging Markets: Sign of a Bumpy Road Ahead? Washington, DC: International Monetary Fund, 2014. Disponível em: <https://goo.gl/ Fiagvg>. Acesso em 24 jun. 2015.

VAN HOREN, F.; PIETERS, R. Preference reversal for copycat brands: Uncertainty makes imitation feel good. Journal of Economic Psychology, Amsterdam, v. 37, p. 54-64, 2013. 
VERGANTI, R. Overcrowded: designing meaningful products in a world awash with ideas. Cambridge, MA: MIT Press, 2016

VOLPATO, N. et al. Prototipagem rápida: tecnologias e aplicações. São Paulo: Blucher, 2007.

WALSH, V. Design, innovation and the boundaries of the firm. Research Policy, Amsterdam, v. 25, n. 4, p. 509-529, 1996

WORLD BANK. Country and Lending Groups. Washington, DC, 2015. Disponível em: <https:// goo.gl/2Bam6h>. Acesso em 24 jun. 2015.
YANG, F. et al. No one likes a copycat: A crosscultural investigation of children's response to plagiarism. Journal of Experimental Child Psychology, Amsterdam, v. 121, p. 111119, 2014

YIN, R. K. Case study research: design and methods. 2. ed. London: Sage, 1994. 171p.

ZURLO, F. Un modello di lettura per il Design Strategico: la relazione tra design e strategia nell'impresa contemporanea. 1999. Dissertação (Doutorado) - Politecnico di Milano, Milão, 1999. 
